\title{
FUMONISINS IN PIG FEED
}

\author{
Sandra Jakšići ${ }^{*}$, Nenad Popov ${ }^{1}$, Milica Živkov Baloš ${ }^{1}$, \\ Jasna Prodanov-Radulović ${ }^{1}$, Biljana Abramović ${ }^{2}$ \\ ${ }^{1}$ Scientific Veterinary Institute „Novi Sad“, Novi Sad, Serbia \\ ${ }^{2}$ University of Novi Sad, Faculty of Sciences, Novi Sad, Serbia
}

\section{Abstract}

Fumonisins are mycotoxins belonging to a group of potential carcinogens for humans. It is well known that they also have potentially harmful effects on various species of animals. After consumption, in the horse they may cause leukoencefalomalation, and in pig pulmonary edema. The legal regulations in Serbia do not prescribe the maximum allowed levels (ML) of fumonisins in feed. As products of Fusarium, fumonisins are often detected in corn, and their presence in wheat is also proven. However, there is not enough data on the occurrence and levels of these mycotoxins in feed. Considering the harmful effect of fumonisin on pig health and data on corn contamination, the aim of this paper is to examine the concentration of fumonisins in feed for pigs. A sum of fumonisins $\left(B_{1}, B_{2}\right.$ and $\left.B_{3}\right)$ in a total of 30 samples of feed for different categories of pigs was tested. Fumonisins were found in $83 \%$ of the examined samples. Although no sample contained more than $5 \mathrm{mg} / \mathrm{kg}$ (the maximum recommended level according to EU regulation), studies on the effect of low-dose toxin on pig health and the frequent grain contamination with multiple mycotoxins pointed out the necessity of monitoring of fumonisins levels in pig feed.

Key words: fumonisins, feed, pig, ELISA

\footnotetext{
${ }^{1^{*}}$ sandra@niv.ns.ac.rs
} 


\title{
FUMONIZINI U HRANI ZA SVINJE
}

\author{
Sandra Jakšić ${ }^{1}$, Nenad Popov ${ }^{1}$, Milica Živkov Baloš ${ }^{1}$, \\ Jasna Prodanov-Radulović ${ }^{1}$, Biljana Abramović ${ }^{2}$ \\ ${ }^{1}$ Naučni institut za veterinarstvo „Novi Sad“, Novi Sad, Srbija \\ ${ }^{2}$ Univerzitet u Novom Sadu, Prirodno-matematički fakultet, Novi Sad, Srbija
}

\section{Kratak sadržaj}

Fumonizini su mikotoksini koji pripadaju grupi potencijalnih karcinogena za ljude. Takođe, veoma su toksični za brojne životinjske vrste. Kod konja nakon unošenja mogu uzrokovati pojavu leukoencefalomalacije, a kod svinja izazivaju pulmonalni edem. Zakonskom regulativom u Srbiji nisu propisane maksimalno dozvoljene količine fumonizina u hrani za životinje. Kao produkti plesni roda Fusarium, fumonizini su često detektovani u kukuruzu, a dokazano je njihovo prisustvo i u pšenici. Međutim, nema dovoljno podataka o rasprostranjenosti i nivou koncentracije ovih mikotoksina u smešama za ishranu životinja. Ukupni fumonizini su ispitani u ukupno 30 uzoraka potpunih smeša za različite kategorije svinja. U $83 \%$ analiziranih uzoraka je utvrđeno prisustvo fumonizina. Iako nijedan uzorak nije sadržao više od $5 \mathrm{mg} / \mathrm{kg}$ (maksimalna preporučena količina saglasno EU regulativi), studije o uticaju niskih doza toksina na zdravlje svinja i čestoj kontaminaciji žitarica sa više mikotoksina upozoravaju na neophodnost praćenja koncentracije fumonizina u hrani za svinje.

Ključne reči: fumonizin, hrana za svinje, ELISA

\section{INTRODUCTION}

The health issues in different pig categories on pig farms are frequently caused directly or indirectly by the present mycotoxins in complete feed (Prodanov-Radulović et al., 2016). In the absence of regular control of feed, various health disorders that indicate mycotoxicosis in different types of pig production systems may occur. Fusarium mycotoxins such as deoxynivalenol and fumonisins are the most common cereal (especially corn) contaminants (Jakšić et al., 2011). 
Fumonisins are a large group of mycotoxins, but most abundant and the most toxic are fumonisins from $B$ group, that is, fumonisin $B_{1}$. In addition to being potentially carcinogenic to humans (IARC, 2002), its toxicity to animals has been confirmed. Given the high percentage of grains in pig feed, and the fact that pigs are monogastric livestock with lack a rumen with a microbiota able to degrade mycotoxins, these animals are practically most vulnerable to fumonisins.

The mechanism of the fumonisin $\mathrm{B}_{1}$ toxicity is related to the structure of this toxin. Namely, it has an unsubstituted primary amino group at $\mathrm{C} 2$ and competitively inhibits ceramide synthase. This results in accumulation of the enzyme's substrates sphinganine ( $\mathrm{Sa}$ ) and sphingosine (So) in tissues, serum, and urine (Dilkin et al., 2010). Fumonisin-induced Sa accumulation is in correlation with onset of apoptosis and mitosis in the liver and kidney of several species including pig (Dilkin et al., 2010).

Consumption of high doses of fumonisins in pigs can induce a specific syndrome known as pulmonary porcine edema. First report of pulmonary edema in pig was noted in 1981 (Kriek et al., 1981). Field cases of pig pulmonary edema and hydrothorax occurred in USA during the 1989 corn harvest, and all cases were in relation with corn contaminated with fumonisin $B_{1}$ (Ross et al., 1991). Pulmonary porcine edema is usually lethal and is characterized by fluid accumulation in the lungs, which has been hypothesized to be due to leftside heart failure mediated by altered sphingolipid biosynthesis (Haschek et al., 2001). The clinical symptoms in addition to pulmonary porcine edema include lower weight gain, poor feed conversion, the clinical signs of cardiovascular, hepatic, and intestinal dysfunction (Haschek et al., 2001; Pierron et al., 2016). It is well known that enteric disease of suckling piglets could be provoked by the feed quality, i.e. the presence of mycotoxins in the feed for lactating sows and in the piglets first feed (Prodanov-Radulović et al., 2014). In conclusion, organs that may be affected by fumonisins in this species are the lungs, liver, heart, and pancreas (Dilkin at al., 2010). Similar as other mycotoxins, fumonisins also impair the immune response and potentially increase susceptibility to various infections (Halloy et al., 2005). Studies showed that fumonisin $B_{1}$ had combined or cummulative effect on animal health with some other toxins, and in combination with a-zearalenol, they may notably impair pig reproductive function activity (Cortinovis et al., 2014).

In animal feed, the European Commission provides recommendations of maximum levels of fumonisin in raw materials and in complete feed for pigs (EC, 2006a; Table 1). Food and Drug Administration in USA also established guidance levels for fumonisins in corn and pig feed (FDA, 2011). 
Table 1. Regulated maximum levels of fumonisins in feed for pigs

\section{Total Fumonisins}

$(\mathrm{mg} / \mathrm{kg})$

Reference

\begin{tabular}{|c|c|c|}
\hline Maize for feed & 60 & \\
\hline $\begin{array}{l}\text { Complementary and complete feed for pigs } \\
\text { (Guidance value relative to a feed } \\
\text { with a moisture content of } 12 \% \text { ) }\end{array}$ & 5 & EC, 2006a \\
\hline $\begin{array}{l}\text { Corn and corn by products not to ex- } \\
\text { ceed } 50 \% \text { of the diet for pig }\end{array}$ & 20 & \multirow[t]{2}{*}{ FDA, 2011} \\
\hline Complete diet for pig & 10 & \\
\hline
\end{tabular}

Fusarium moulds are often isolated from the feed materials produced in Serbia, and fumonisins are detected as an inevitable metabolite, especially on corn (Jakšić et al., 2011). However, the legal regulations in Serbia do not prescribe the ML of fumonisins in feed, and also there are no recommendations on their control and maximum levels. Considering the harmful effect of fumonisins on pig health and data about corn contamination, the aim of this paper was to examine the concentration of fumonisins in complete feed for different categories of pigs.

\section{MATERIAL AND METHODS}

In the period from January to June 2018, in the laboratory of Scientific Veterinary Institute „Novi Sad“, different pig feed samples were analyzed for the content of the total fumonisins $\left(B_{1}, B_{2}\right.$ and $\left.B_{3}\right)$. Feed samples were collected from feed producers and directly from different pig farms. Immediately upon sampling, $1000 \mathrm{~g}$ of each sample was prepared by grinding in a laboratory mill in such a way that $>93 \%$ passes through a $0.8 \mathrm{~mm}$ sieve. The samples were than homogenized by mixing, packed in plastic bags and stored at $-20^{\circ} \mathrm{C}$ in a freezer. The samples were allowed to reach room temperature prior to analysis.

Determination of fumonisins level using Enzyme Linked Immunosorbent Assay (ELISA) method was performed applying ELISA Veratox for Fumonisin $5 / 10$ test kit (Neogen, USA). The analytical quality of the ELISA method was assured by the use of certified reference materials as well as by participation in interlaboratory studies. For validation and analytical quality of the ELISA method, there was used naturally contaminated maize reference material with certified fumonisins content of $2.1 \pm 0.1 \mathrm{mg} / \mathrm{kg}$ (TR-F100, lot \#F-C-439, Tril- 
ogy Analytical Laboratory, Washington, USA). The validation parameters were calculated and expressed using procedure according to Council Directive 96/23/EC (EC, 2002), and the obtained values were in accordance with recommendations given in EU Regulation 2006/401 (EC, 2006b). Laboratory limit of detection was $0.2 \mathrm{mg} / \mathrm{kg}$, and limit of determination $0.5 \mathrm{mg} / \mathrm{kg}$. Recovery was $108 \%$. Furthermore, the analytical quality of the ELISA method was assured by participation in proficiency testing schemes (MPZ UKZUZ, 2014 and 2018).

\section{RESULTS AND DISCUSSION}

The results of fumonisins content in pig feed samples are presented in Table 2.

Table 2. Contents of fumonisins in pig feed samples from Serbia in 2018

\begin{tabular}{lcccccc}
\hline $\begin{array}{c}\text { Complete } \\
\text { pig feed }\end{array}$ & $\begin{array}{c}\text { Positive / } \\
\text { total no. } \\
\text { of samples }\end{array}$ & $\begin{array}{c}\text { Positive } \\
\text { samples }\end{array}$ & $\begin{array}{c}\text { Min } \\
(\mathrm{mg} / \mathrm{kg})\end{array}$ & $\begin{array}{c}\text { Max } \\
(\mathrm{mg} / \mathrm{kg})\end{array}$ & $\begin{array}{c}\text { Average } \\
(\mathrm{mg} / \mathrm{kg})\end{array}$ & $\begin{array}{c}\text { Median } \\
(\mathrm{mg} / \mathrm{kg})\end{array}$ \\
\hline Piglets & $7 / 10$ & 70 & 0.234 & 3.54 & 1.02 & 0.672 \\
\hline Fattening pigs & $9 / 10$ & 90 & 0.263 & 1.79 & 0.770 & 0.659 \\
\hline Sows & $5 / 5$ & 100 & 0.845 & 2.15 & 1.15 & 1.05 \\
\hline Boars & $4 / 5$ & 80 & 0.218 & 0.729 & 0.550 & 0.703 \\
\hline Total & $25 / 30$ & 83 & 0.218 & 3.54 & 0.893 & 0.685 \\
\hline
\end{tabular}

As it can be seen from obtained results, fumonisins are frequent contaminants of feed for all pig categories. In $83 \%$ of analysed samples, fumonisins are detected by applied method in average concentration of $0.893 \mathrm{mg} / \mathrm{kg}$. The highest mean value of fumonisins concentration is determined in samples intended for sows feeding $(1.15 \mathrm{mg} / \mathrm{kg})$, and in this type of samples the most frequent contamination with fumonisins was noted (100\%). Although the measured concentrations in all investigated samples did not exceed the maximum recommended level according to EU regulation $(5 \mathrm{mg} / \mathrm{kg})$, the fact that the highest concentration $(3.54 \mathrm{mg} / \mathrm{kg})$ was recorded in the feed sample for a category whose health is important for long-term farm production is worrying. To the best of our knowledge, in the literature there is almost no data on fumonisins in pig feed to compare with obtained results. Data from our previous investigation are comparable with the obtained results (Jakšić et al., 2015). In 2014, slightly smaller number of samples was analyzed, all of them were positive for fumonisins, with a lower maximum concentration $(2.15 \mathrm{mg} / \mathrm{kg})$, and higher average value $(1.42 \mathrm{mg} / \mathrm{kg})$, if compared with this research.

Still, the question is: could these concentrations yet cause health problems 
in pigs? As it was said in the introduction, the fumonisin toxicity in pigs is well proven and it varies according to several parameters such as the dose, the duration of exposure, the age, and the sex of the animal, with the greater effects on performance in males and younger pig categories (Andretta et al., 2012). Exposure to an average concentration of fumonisins in naturally contaminated feed had effect on the digestive microbiota balance, with Salmonella exposure amplifying this phenomenon (Burel et al., 2013). In growing pigs, the presence of fumonisin $B_{1}$ at concentrations of more than $0.1 \mathrm{mg} / \mathrm{kg}$ resulted in a lower weight gain, while in the final fattening concentrations from $1 \mathrm{mg} / \mathrm{kg}$ of toxin can have a negative effect on the quality of meat (increased fat and reduced meat percentage) and cause economic losses to producers (Rotter et al., 1994).

The important question is: it is possible to spot and prevent health problems of low fumonisin concentrations in feed? The first clinical symptoms of intoxication are nonspecific and can easily be unnoticed and mistaken for other diseases. Oral administration of fumonisins at level of $5 \mathrm{mg} / \mathrm{kg}$ body weight to pig, induced clinical alterations compatible to pulmonary porcine edema (Dilkin et al., 2010). However, low doses of fumonisins can induce various hematological changes and pathological signs that are not specific and not sufficient to diagnose fumonisin intoxication, although biochemical and clinical alterations might be in some cases indicative. Liver alterations are detected through increase in certain enzymes, such as alkaline phosphatase, sorbitol dehydrogenase, aspartate aminotransferase, and gamma-glutamyl transpeptidase (Riley et al., 1993). In some cases, serum cholesterol and biliary acid concentrations also show significant increases (Casteel et al., 1994). Free sphinganine ( $\mathrm{Sa})$ and sphinganine to sphingosine ratio $(\mathrm{Sa} / \mathrm{So})$ could be used as a sensitive marker for fumonisin exposure, since the highest $\mathrm{Sa}$ and $\mathrm{Sa} / \mathrm{So}$ ratios were obtained at 12 and $48 \mathrm{~h}$ after toxin administration (Dilkin et al., 2010). Fumonisins are poorly absorbed from the gastrointestinal tract (Pierron et al., 2016). They have a low elimination rate in urine $(0.93 \%)$, while larger amounts of fumonisins can be detected in feces (76.5\%; Dilkin et al., 2010). Accumulation in tissues is greatest in the liver and kidneys (Prelusky et al., 1996). There is also possibility to evaluate hair as a biomarker to assess the dietary exposure of pigs to fumonisins (Souto et al., 2017).

It was found that fumonisin $\mathrm{B}_{1}$ has immunosuppressive effect on humoral immune response in pigs, and therefore can provoke some secondary bacterial (Escherichia coli, Pasteurella multocida) (Halloy et al., 2005) or complications with the viral infections (porcine reproductive and respiratory syndrome) (Ramos et al., 2010), which can arise in immunocompromised animals. 


\section{CONCLUSSION}

There is a factual risk of pig feed contamination with fumonisins in Serbia, especially after climatic changes during the last decade. Although measured concentrations of toxin levels were lower than recommended, it should be considered the effects of chronic exposure to such low dietary levels of fumonisin $B_{1}$ in pigs, which were found under natural conditions. Avoiding economic losses due to presence of fumonisins in pig feed, it is necessary to control these mycotoxins in corn. In order to ensure safe feed, it is necessary to take into account both the presence of fumonisins themselves and other mycotoxins due to the possible additive and synergistic negative effects of the mycotoxin mixture.

\section{ACKNOWLEDGEMENT}

This paper is published as part of the project of the Ministry of Education, Science and Technological Development of Republic of Serbia No. 172042.

\section{REFERENCES}

1. Andretta I., Kipper M., Lehnen C.R., Hauschild L., Vale M.M., Lovatto P.A.: Meta-analytical study of productive and nutritional interactions ofmycotoxins in growing pigs. Animal, 6, 1476-1482, 2012.

2. Burel C., Tanguy M., Guerre P., Boilletot E., Cariolet R., Queguiner M., Postollec G.,Pinton P., Salvat G., Oswald I., Fravalo P.: Effect of low dose of fumonisins on pig health: immune status,intestinal microbiota and sensitivity to Salmonella. Toxins (Basel), 5, 841-864, 2013.

3. Casteel S.W., Turk J.R., Rottinghaus G.E.: Chronic effects of dietary fumonisin on the heart and pulmonary vasculature of swine. Fundamental and Applied Toxicology, 23, 518-524, 1994.

4. Cortinovis C., Caloni F., Schreiber N.B., Spicer L.J.: Effects of fumonisin B1 alone and combined with deoxynivalenol or zearalenone on porcine granulosa cellproliferation and steroid production. Theriogenology, 81, 1042-1049, 2014.

5. Dilkin P., Direito G., Simas M.M.S., Mallmann C.A., Corrêa B.: Toxicokinetics and toxicological effects of single oral dose of fumonisin $B_{1}$ containing Fusarium verticillioides culture material in weaned piglets, ChemicoBiological Interactions, 185, 157-162, 2010. with references cited therein.

6. EC (European Commission): Commission decision of 12 August $2002 \mathrm{im}-$ plementing Council Directive 96/23/EC concerning the performance of 
analytical methods and the interpretation of results. 2002/657/EC, O. J., L 285: 33-37. L 221: 8-36, 2002.

7. EC (European Commission): Commission Recommendation of $17 \mathrm{Au}-$ gust 2006 on the presence of deoxynivalenol, zearalenone, ochratoxin A, T-2 and HT-2 and fumonisins in products intended for animal feeding. 2006/576/EC, O. J., L 229, 7-9, 2006 a.

8. EC (European Commission): Commission Regulation No 401/2006 of 23 February 2006, laying down the methods of sampling and analysis for the official control of the levels of mycotoxins in foodstuffs, O. J. 2006, L 70: 12-34, 2006b.

9. FDA, National Grain and Feed Association Mycotoxin Regulatory Guidance, 2011.

10. Halloy D.J., Gustin P.G., Bouhet S., Oswald I.P.: Oral exposure to culture material extract containing fumonisins predisposes swine to the development of pneumonitis caused by Pasteurella multocida. Toxicology, 213, 34-44. 2005.

11. Haschek W.M., Gumprecht L.A., Smith G., Tumbleson M.E., Constable P.D.: Fumonisin toxicosis in swine: An overview of porcine pulmonary edema and current perspectives. Environmental Health Perspectives, 109, 251-257, 2001.

12. IARC - International Agency for Research on Cancer. IARC Monograph on the Evaluation of Carcinogenic Risk to Humans. 82, 171. 2002.

13. Jakšić S., Prunić B., Milanov D., Jajić I., Bjelica L., Abramović B.: Fumonisins and co-occurring mycotoxins in north Serbian corn. Zbornik Matice srpske za prirodne nauke, 120, 49-59, 2011.

14. Jakšić S., Živkov-Baloš M., Prica N., Mašić Z., Nešić K., Jajić I., Abramović B.: The influence of climatic factors in Serbia on mycotoxin production. Proceedings, First International Symposium of Veterinary Medicine 'One Health - New Challenges' (ISVM2015), Vrdnik, May 21-23, 2015, 166-172.

15. Kriek N.P.J., Kellerman T.S., Marasas W.F.O.: A comparative study of the toxicity of Fusarium moniliforme to horses, primates, pigs, sheep and rats. Onderstepoort Journal of Veterinary Research, 48, 129-131, 1981.

16. Pierron A., Alassane-Kpembi I., Oswald I.P.: Impact of two mycotoxins deoxynivalenol and fumonisin on pig intestinal health. Porcine Health Management, 2, 21-28, 2016.

17. Souto P.C.M.C., Jager A.V, Tonin F.G., Petta T., Di Gregorio M.C., Cossalter A.M., Pinton P., Oswald I.P., Rottinghaus G.E., Oliveira C.A.F.: Determination of fumonisin B1 levels in body fluids and hair frompiglets fed fumonisin B1-contaminated diets. Food and Chemical Toxicology, 108, 1-9, 2017. 
18. Prelusky D.B., Trenholm H.L., Rotter B.A., Miller J.D., Savard M.E., Yeung J.M., Scott P.M.: Biological fate of fumonisin B1 in food-producing animals. Advances in Experimental and Medicinal Biology, 392, 265-278, 1996.

19. Prodanov-Radulović J., Došen R., Stojanov I., Polaček V., Milanov D., Pušić I., Grubač S.: Neonatal diarrhea in pigs caused by Clostridium perfringens. Arhiv veterinarske medicine, 7, 49-58, 2014.

20. Prodanov-Radulović J., Živkov Baloš M., Jakšić S., Stojanov I., Petrović J., Ratajac R., Bojkovski J.: Evalution of influence of Fusarium mycotoxins on intensity of intestinal swine diseases. Proceedings of XVII International Symposium "Feed Technology" (“Celebrating Food"), Novi Sad, Serbia, October 25-27, 2016, 106-112.

21. Ramos C.M., Martinez E.M., Carrasco A.C., Puente J.H.L., Quezada F., Perez J.T., Oswald I.P., Elvira S.M.: Experimental trial of the effect of fumonisin B1 and the PRRS virus in swine. Journal of Animal and Veterinary Advances, 9, 1301-1310, 2010.

22. Riley R.T., An N.Y., Showker J.L., Yoo H.S., Norred W.P., Chamberlain W.J., Wang E., Merrill A.H.J., Motelin G., Beasley V.R., Haschek W.M.: Alteration of tissueand serum sphinganine to sphingosine ratio: an early biomarker in pigs ofexposure to fumonisin-containing feeds. Toxicology and Applied Pharmacology, 118, 105-112, 1993.

23. Ross P.F., Rice L.G., Plattner R.D., Osweiler G.D., Wilson T.M., Owens D.L., Nelson H.A., Richard J.L.: Concentrations of fumonisin B1 in feeds associated with animal health problems. Mycopathologia, 114, 129-135, 1991.

24. Rotter B.A., Thompson B.K., Lessard, M., Trenholm, H., Tryphonas H.: Influence of low level exposure of fusarium mycotoxins on selected immunological and hematological parameters in young swine. Fundamental and Applied Toxicology, 23, 117-124, 1994.

Primljeno: 01.11.2018.

Odobreno: 20.11.2018. 